\title{
Circulation Space in the Library Reading Room of University of Lampung
}

\author{
Neneng Widiana ${ }^{1}$, Ai Siti Munawaroh ${ }^{2}$ \\ ${ }^{1,2}$ Department of Architecture, Faculty of Engineering, Universitas Bandar Lampung, Indonesia \\ aisiti.arch@ubl.ac.id \\ *Corresponding Author, Received: 19 Nov. 2020, Revised: 27 Nov. 2020, Accepted: 02 Dec. 20200
}

\begin{abstract}
University of Lampung (Unila) is the first and oldest public university in Lampung Province, having a Library Technical Implementation Unit (UPT) with a centralized library system. As one type of public space, UPT Unila library is the most widely visited place as a place to find references or others. The number of library visitors who carry out activities will affect the comfort of each user's circulation. The purpose of this study was to determine the user's circulation in the library reading room. The method used is descriptive qualitative. Data obtained through the depiction of a floor plan, measurement of the distance between furniture and the area of the room using a meter. The analysis is done by comparing the measurement results with the standard of circulation. The results showed that the circulation in the library reading room of the University of Lampung has not approached the distance in accordance with the standards. The distance between the reading tables in the reading room is less than the standard, while the distance of traffic between the bookshelf and the reading table exceeds the recommended standard.
\end{abstract}

Keywords: anthropometry, library, reading room, circulation, unila

\section{INTRODUCTION}

Based on Law (UU) No. 43 of 2007 on the library in article 4 stated that the library aims to provide services to users (library users), increase reading fondness, and broaden their insights and knowledge to educate the nation's life [1]. In Law UU No. 2 of 1989 concerning the National Education System in article 55 states that one of the requirements for organizing Higher Education must have a Library [2].

The existence of higher education libraries aims to assist universities in implementing the Tri Dharma of higher education namely education, research and community service. The purpose of higher education libraries is to meet the information needs of teachers and students, provide reference library materials at all academic levels, provide space for users and provide loan services and provide active information services for users [3].

As a means of education and learning tools for the community, libraries are also required to be able to provide satisfaction to users through services and spatial planning. User satisfaction with library services, one of which is determined by the room and supporting equipment arranged properly and comfortably. Within the scope of circulation, comfort and user satisfaction, a design that is responsive to human dimensions and body size is very much needed [4].
Some researches on libraries have been carried out, including on visual comfort $[5,6]$ and thermal comfort $[7,8]$. But no one has researched the circulation yet. Especially research about circulation in the reading room.

The use of facilities by library users causes many areas to become joint activity zones which actually disturb the comfort of other users. Such as the distance between the collections of shelves that cause contact between one user and another, the distance between the collection rack and the reading table that interferes with the circulation of the library user, the distance between the chairs is narrow so that it interferes with the circulation paths of other users and users who sit behind them.

University of Lampung (Unila) is the first and oldest public university in Lampung Province, having a Library Technical Implementation Unit (UPT) with a centralized library system. As one type of public space, UPT Unila library is the most widely visited place as a place to find references or others. The number of library visitors who carry out activities will affect the comfort of each user's circulation. Therefore, it is necessary to do research on the circulation of the movement space at the University of Lampung library.

The problem in this study is the circulation of the space in the Lampung University library. The scope of the problem in this research is the study of 
user space circulation in the library reading room of the University of Lampung. Based on the problem limitation or scope of the discussion above, it has been found that the formulation of the problem is how the circulation of the user's space in the library reading room based on standard. The purpose of this study was to determine the user's room circulation in the library reading room based on standard.

Through this research it is expected to provide benefits for many people. The benefits obtained from the holding of this research is that it can contribute knowledge about the planning standards of the university Library so that it can achieve the vision and mission of the university library in the future.

\section{LITERATURE REVIEW}

\section{Circulation}

Circulation has the meaning as circulation in one place to another. Space to move/circulation space is defined as a rope that is seen to connect the spaces of a building or one part with another inside and outside the building [9].

\section{Standards of Circulation in the Reading Room}

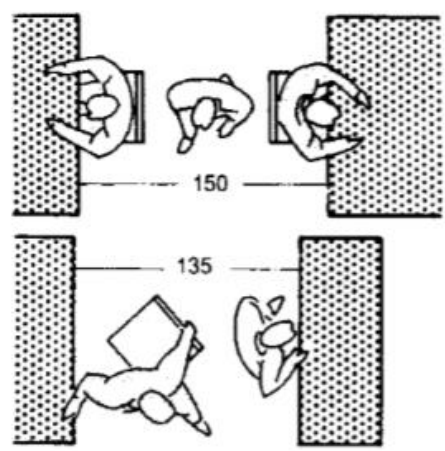

Figure 1. Standards of Distance Between Reading Tables [10]

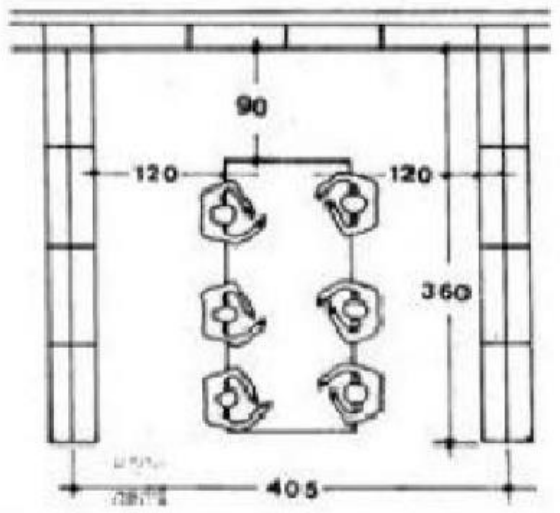

Figure 2. Standards of distance between reading tables and collection racks [10]
Whereas what happens in reading rooms during activities is sit, shift chairs, read, and cross physical contact will occur when the narrow distance between the reading table. And to get comfort while reading by reducing contact between users who are reading with users who are crossing, the recommended net distance [10] for sitting and standing movements is $135 \mathrm{~cm}$ and for the net distance of movement traffic when sitting and standing with there are other users who pass by at least $150 \mathrm{~cm}$.

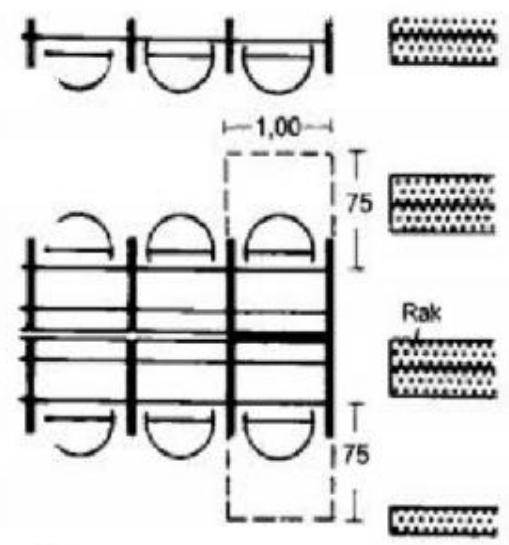

Figure 3. Standard distance measurements for personal tables

And for personal table spacing according to [10], the width of the personal table is $100 \mathrm{~cm}$ and the distance of the table to the chair when the user sits $75 \mathrm{~cm}$. while the distance between the tables that are back to back with a chair is recommended at least $140 \mathrm{~cm}$.

\section{METHODS}

\section{Research Approach}

Uses a descriptive qualitative research approach. According to [11] descriptive research is a research method used to find the widest possible knowledge of the object of research at a particular time. Meanwhile, according to [12] descriptive research is research that aims to explain or describe a situation, event, object whether a person, or everything related to variables that can be explained both with numbers and words. The same thing also stated by Best in [13] that descriptive research is a research method that seeks to describe and interpret objects according to what they are.

\section{Time and Place of Research}

Time of this research was conducted on 15 - 31 October 2018 in the reading room of the Unila 
library, to collect data on the existing condition of the research object.

Unila library located on J1 Soemantri Brojonegoro Meneng Building, Gedong Meneng, Rajabasa, Bandar Lampung City, Lampung.

\section{Sample Techniques}

In this study the authors took a method purposive sampling at the University of Lampung (Unila). This is based on the fact that Unila is the first and oldest state university in Lampung Province, and has a Library Technical Implementation Unit (UPT). Unila Library A accredited A is the author's consideration, to make the reading room of the Unila library as a comparison with applicable standards.

\section{Data Collection Techniques}

Collection techniques used in this study are field observations and measurements. Data in the form of floor plans and documentation of the situation in the Library. The research data collection is as follows:

- Data about the library reading room plan at the University of Lampung.

- Measurement of the distance between furniture and the area of the room in the library is measured with a meter.

\section{Instruments}

Research tools used in the study are as follows:

- Mobile camera, used to retrieve documentation during the field survey process.

- The meter is used to measure the area of space and the distance between furniture during field surveys.

\section{Data Analysis Techniques}

Technical analysis in this study was compared the results of data analysis of the circulation space of the library reading room of the University of Lampung with the circulation of movement space standard.

\section{RESULTS AND DISCUSSION}

Reading room in the reading room of the University of Lampung library which consists of 3 floors, has a separate layout or not in 1 (one) area on each floor, explained as follows:

\section{Reading Room $1^{\text {st }}$ Floor}

There are 2 zone zones in the room read the $1^{\text {st }}$ floor of the University of Lampung library, as shown in the following figure:

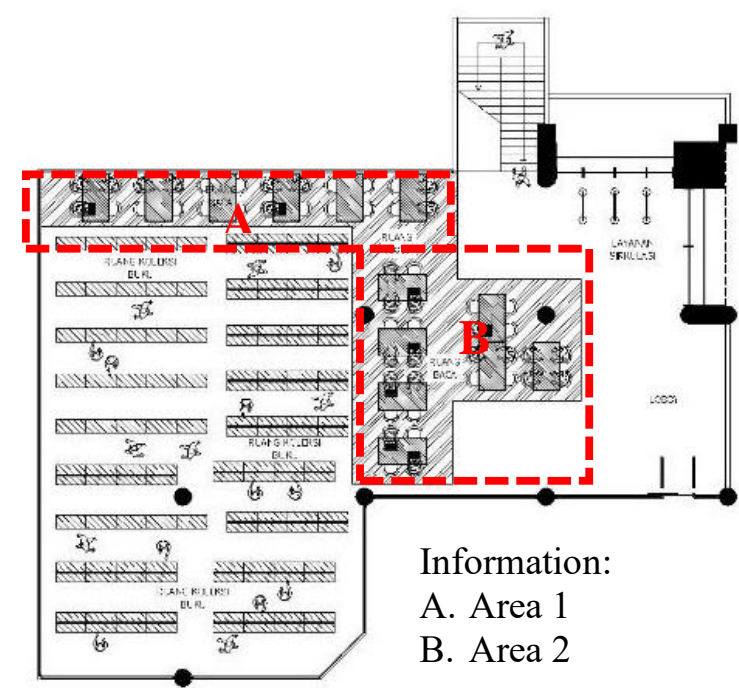

Figure 4. Reading Room Zone $1^{\text {st }}$ Floor

At the reading room on the $1^{\text {st }}$ floor the University of Lampung library has 52 units of seats divided into 2 zones, which are in the zone 1 there are 28 seats and zone 224 seats are provided for users. As shown in the following figure:

\section{Zone 1}

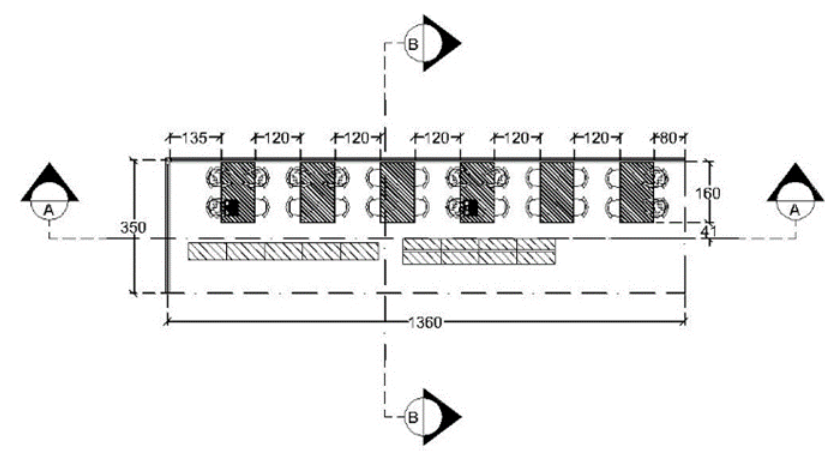

Figure 5. $1^{\text {st }}$ Floor Plan Reading Room Zone 1

The reading room in zone 1 has a distance between a reading table of $120 \mathrm{~cm}$ and a distance between a reading table with a wall of $135 \mathrm{~cm}$, while the distance reading table with a collection rack of $65 \mathrm{~cm}$

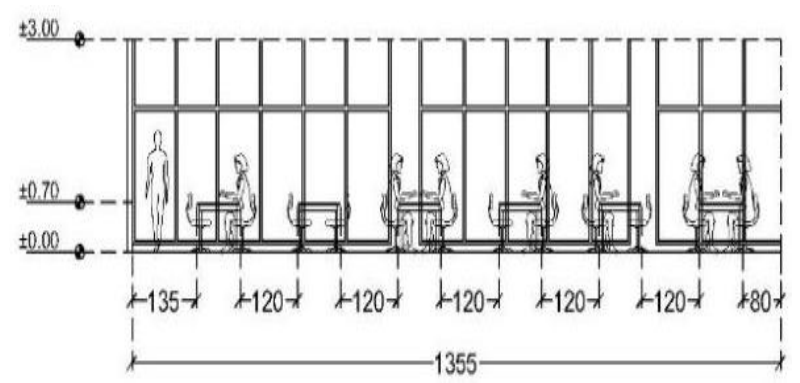

Figure 6. A-A Section of Reading Room on the $1^{\text {st }}$ Floor Zone 1 


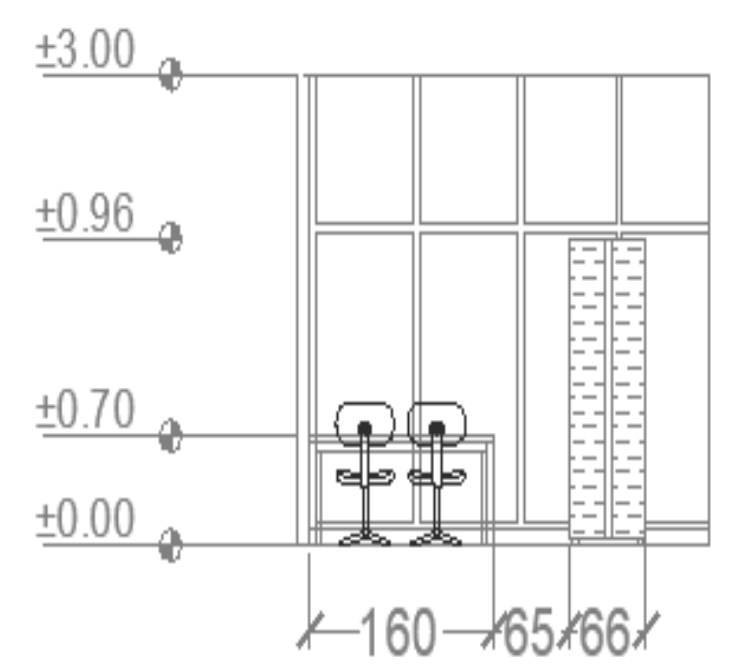

Figure 7. B-B Section Reading Room on the $1^{\text {st }}$ Floor Zone1

\section{Zone 2}

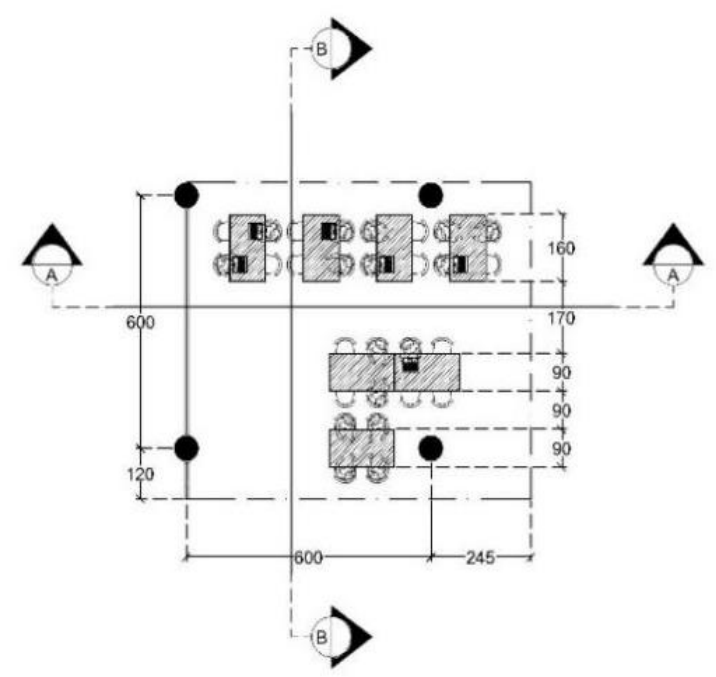

Figure 8. The $1^{\text {st }}$ Floor Plan of Reading Room Zone 2

While in zone 2 the distance between reading tables is $90 \mathrm{~cm}$ and the distance between reading tables for user traffic is $170 \mathrm{~cm}$.

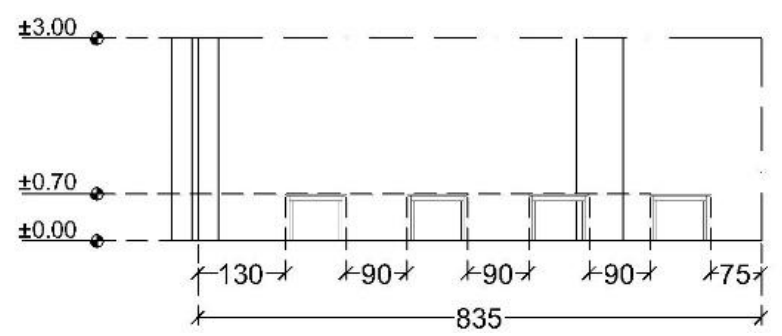

Figure 9. A-A Section Reading Room on the $1^{\text {st }}$ Floor Zone 2

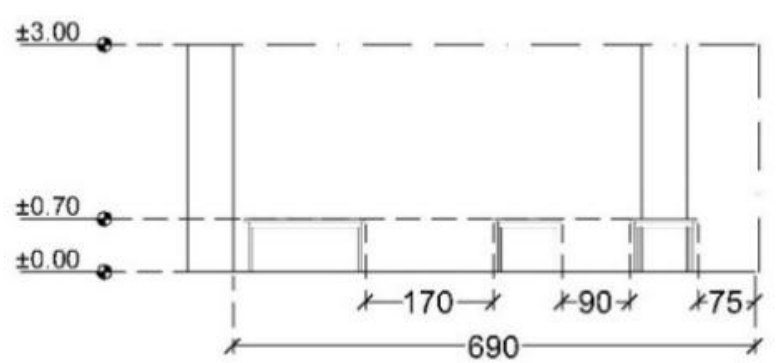

Figure 9. B-B Section Reading Room on the $1^{\text {st }}$ Floor Zone 2

The distance between the furniture in the reading room on the $1^{\text {st }}$ floor has a gap that is too narrow resulting in the circulation of user space to be disturbed. According to [10] the standard measure of the distance between the reading table and other furniture in the reading room is the distance between the reading table that is $135 \mathrm{~cm}$ $190 \mathrm{~cm}$, while the distance between the reading table and other furniture such as cabinets/shelves collection is $90 \mathrm{~cm}-120 \mathrm{~cm}$. The following is a comparison of the standard analysis of the distance between furniture in the reading room on the $1^{\text {st }}$ floor. In the reading room on the $1^{\text {st }}$ floor was against the standard measurement of the standard distance.

Table 1. Comparison of the measurement of the distance Furnitures

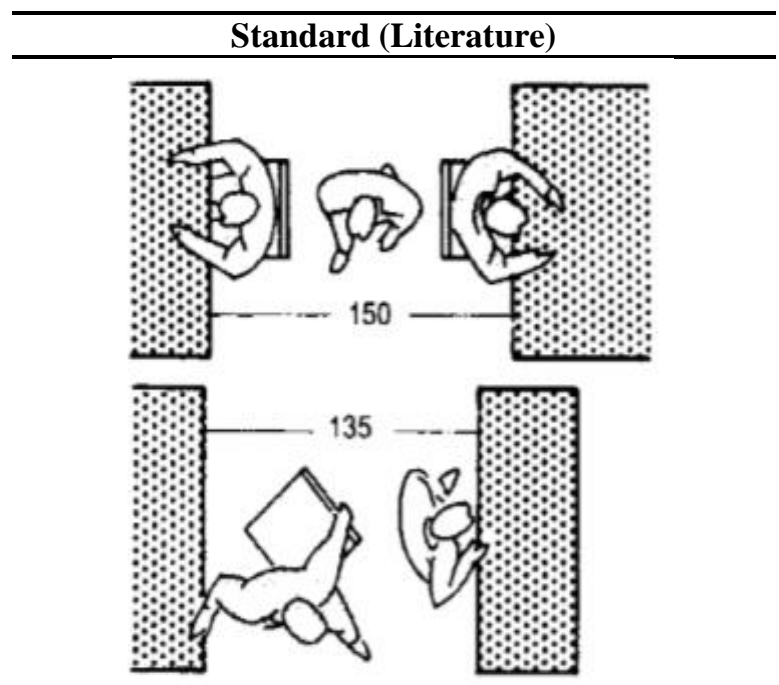

In the reading room activities such as sitting, reading, walking the minimum space needed within the range between the table when sitting position is $135 \mathrm{~cm}$, while the minimum distance between tables for movement of traffic when sitting and standing is $150 \mathrm{~cm}$. 


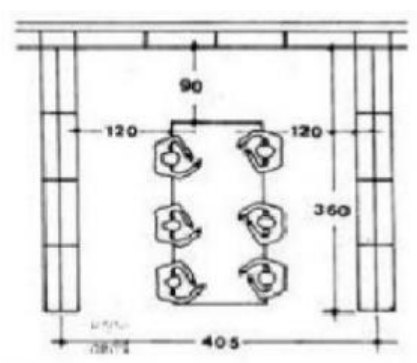

The minimum distance between a bookshelf and a reading table is $90 \mathrm{~cm}$ without a chair, while the minimum distance between a bookshelf and a reading table with a chair as shown is $120 \mathrm{~cm}$.

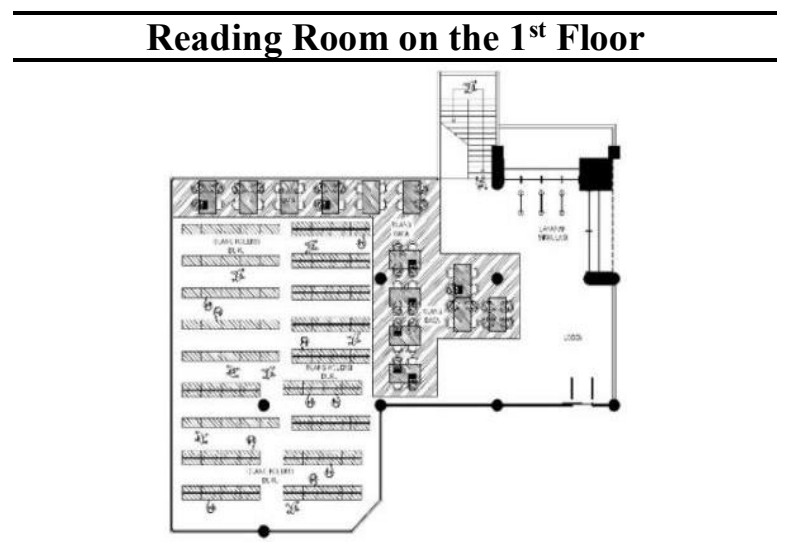

The distance between the reading table in the first-floor reading room is $90 \mathrm{~cm}-120 \mathrm{~cm}$. The distance between the tables when sitting position is too narrow resulting in the user not comfortable in carrying out their activities, while the distance for the road traffic that is 170 $\mathrm{cm}$ distance has to pay attention to the recommended distance size standard.

(Source: Results of Analysis, 2019)

From the table above the circulation in the reading room of the $1^{\text {st }}$ floor, the distance between the reading tables is less than the standard, while the circulation for the road traffic has a distance that exceeds the standard, according to [10] the recommended distance is $135 \mathrm{~cm}-150 \mathrm{~cm}$. And the distance between the reading tables in the presence of a collection rack has a size that is less than the standard, according to [10] the size of the distance between the reading table without a chair to the collection rack is $90 \mathrm{~cm}$.

\section{Reading room on the $2^{\text {nd }}$ floor}

Reading room on the $2^{\text {nd }}$ floor in the reading room of the University of Lampung library has a capacity of 32 seating chairs for visitors; the reading room on the $2^{\text {nd }}$ floor is divided into 2 zone areas, as shown in the following figure:

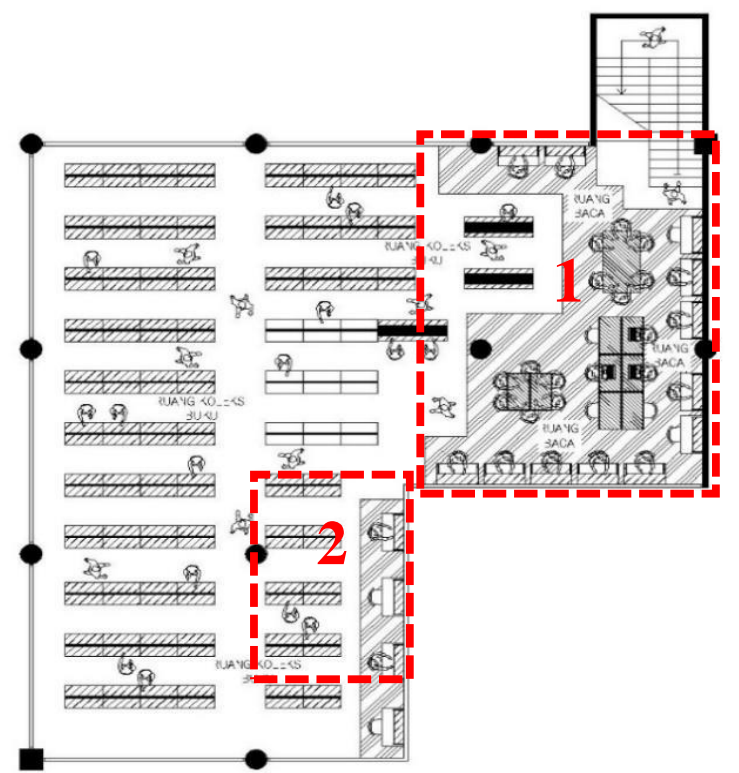

Figure 10. Reading Room Zone on the $2^{\text {nd }}$ Floor

\section{Zone 1}

In zone 1 reading room on the $2^{\text {nd }}$ floor there are several furniture inside such as reading tables 2 , 3 , and 4 as well as collection shelves 5 . The layout between reading tables in zone 1 are close to each other, as shown in the following figure:

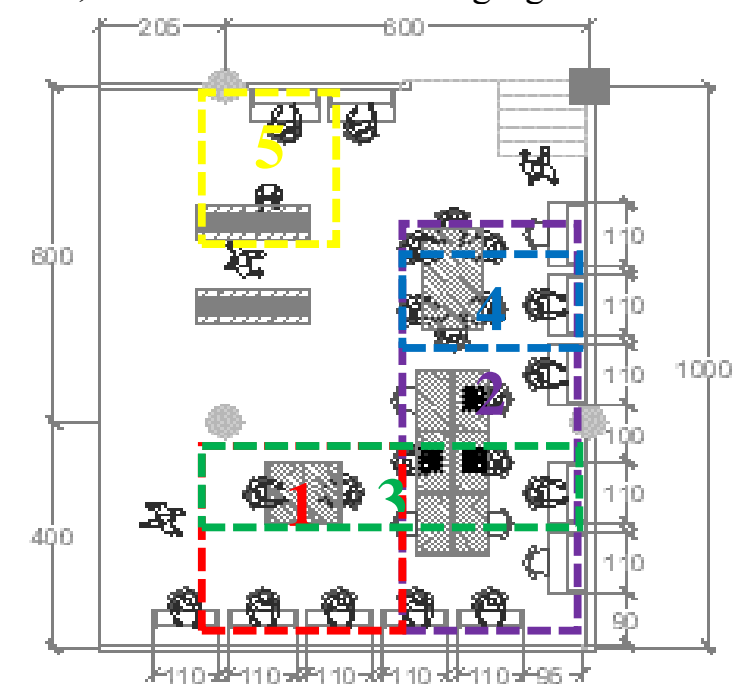

Figure 11. the $2^{\text {nd }}$ Floor Plan of Reading Room

Information:

Detail 1 Detail 2

Detail 3 Detail 4

Detail 5

Zone 1

Detail 1

In detail 1 there is a reading table 2 and reading table 3 which has a distance of $155 \mathrm{~cm}$. 


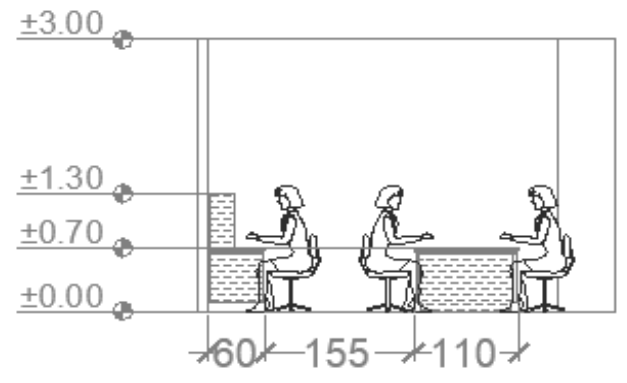

Figure 12. Detail 1 Reading Room $2^{\text {nd }}$ Floor Zone 1

\section{Detail 2}

In detail 2 there is a circulation distance between the reading table and stairs that is $135 \mathrm{~cm}$, there are also reading tables 2,3 and 4 with the distance between the reading table i.e. $65 \mathrm{~cm}-100$ $\mathrm{cm}$.

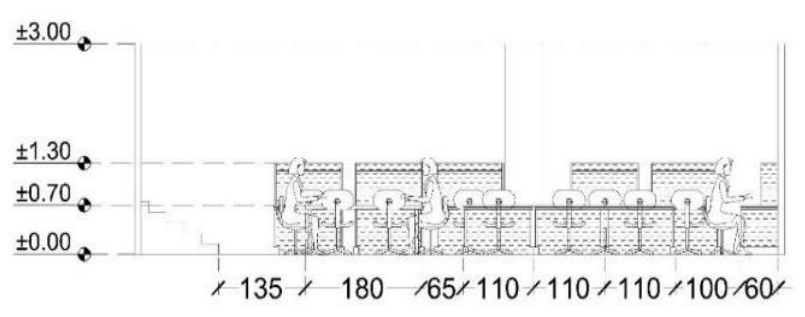

Figure 13. Detail 2 Reading Room on the $2^{\text {nd }}$ Floor Zone 1

Detail 3

In detail 3 there are 2 types of reading tables namely reading tables 2 and 3 , which have a distance between reading tables that is $97.5 \mathrm{~cm}-125$ $\mathrm{cm}$.

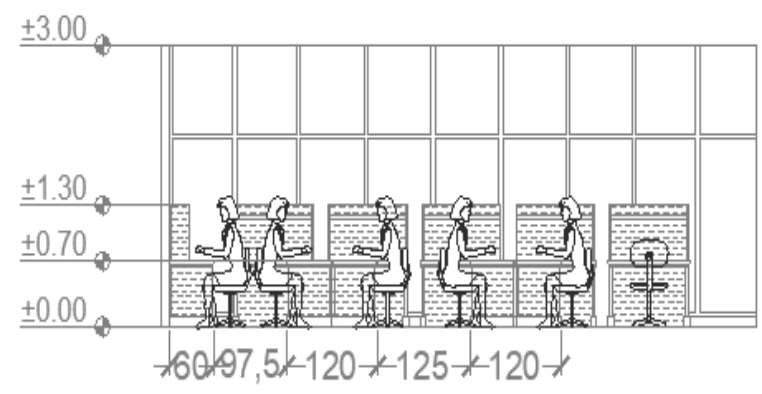

Figure 14. Detail 3 Reading Room on the $2^{\text {nd }}$ Floor Zone 1

\section{Detail 4}

In detail 4 , the distance between reading table 2 and reading table 4 is $107.5 \mathrm{~cm}$.

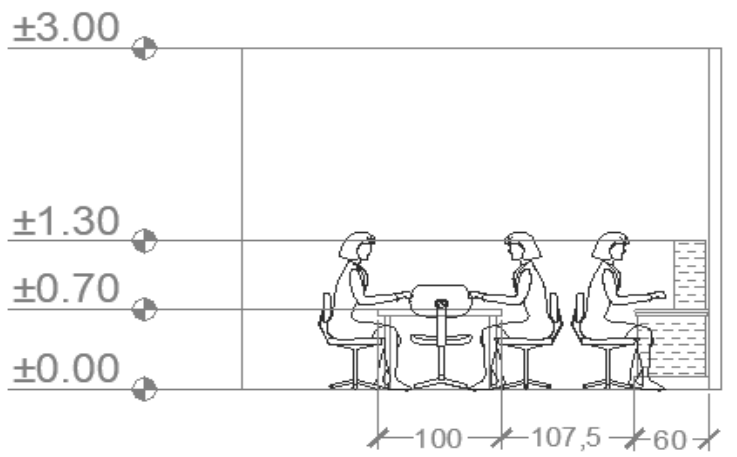

Figure 15. Detail 4 Reading Room on the $2^{\text {nd }}$ Floor Zone 1

Detail 5

There is a reading table 2 and collection rack 5 in detail 5, with the distance between the reading table with a chair with a collection rack that is 148 $\mathrm{cm}$.

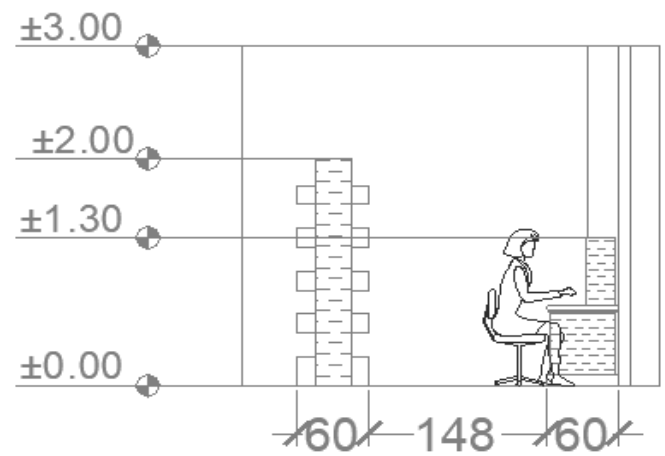

Figure 16. Detail 5 Reading Room on the $2^{\text {nd }}$ Floor Zone 1

\section{Zone 2}

In the reading room zone 2 there is a collection rack 4 and reading table 2 arranged in parallel, as shown in the following figure:

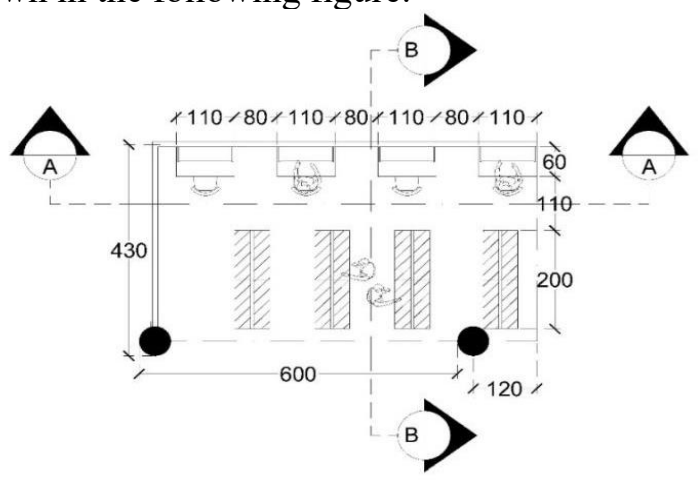

Figure 17. Reading Room on the $2^{\text {nd }}$ Floor Zone 2 
The distance between furniture in zone 2 includes the distance between personal reading tables, which is $80 \mathrm{~cm}$ and the distance between tables with chairs to the collection shelves, $110 \mathrm{~cm}$.

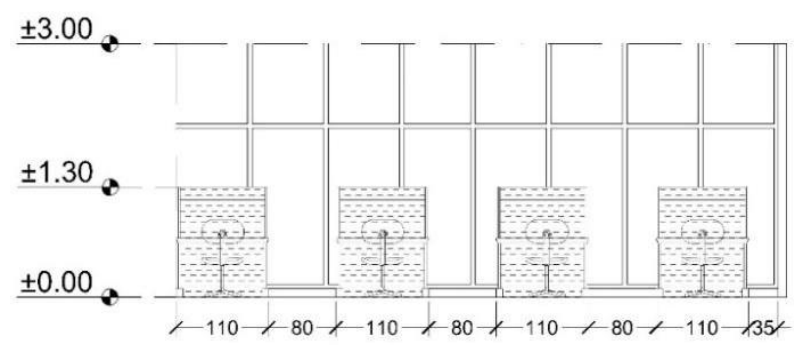

Figure 18. Section of Reading Room on the $2^{\text {nd }}$ Floor Zone 2

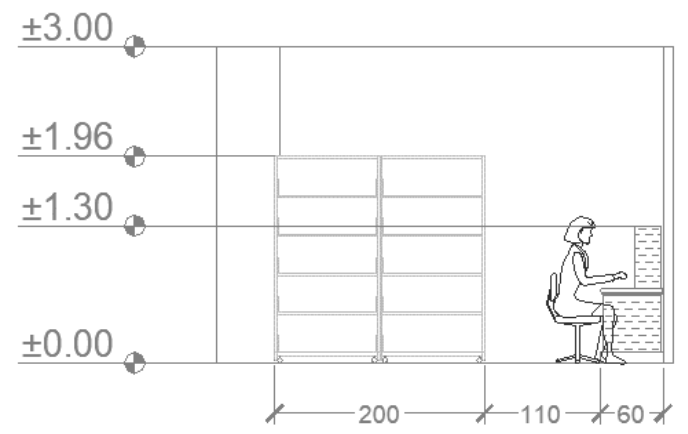

Figure 19. Section of Reading Room on the $2^{\text {nd }}$ Floor Zone 2

In reading room on the $2^{\text {nd }}$ floor has a distance between the reading table that is too narrow resulting in ineffective users in the movement when reading in the room. The following is a comparison of the standard analysis of the distance between furniture in the reading room on the $1^{\text {st }}$ floor.

Table 2. Comparison of the measurement of the distance of Furnitures on the $2^{\text {nd }}$ floor against the standard measure of the distance

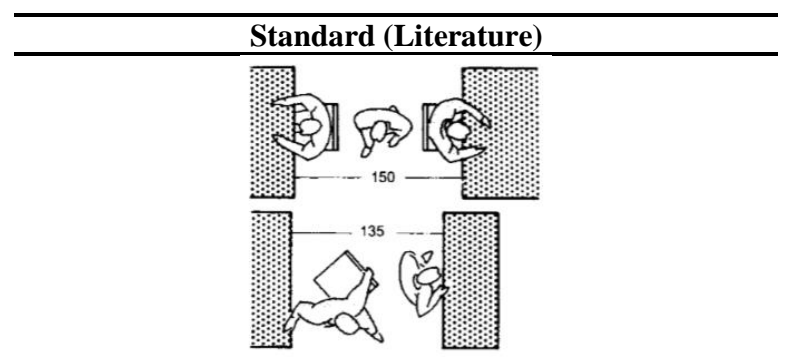

In the reading room activities that occur such as sitting, reading, walking the minimum space needed within the range between the table when sitting position is $135 \mathrm{~cm}$, while the minimum distance between tables for movement of traffic when sitting and standing is $150 \mathrm{~cm}$.

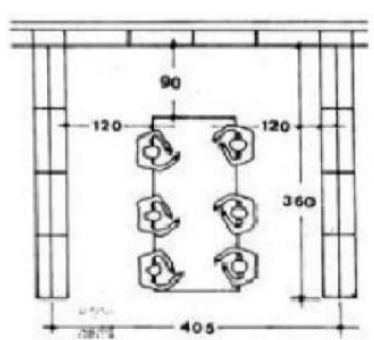

The minimum distance between a bookshelf and a reading table is $90 \mathrm{~cm}$ without a chair, while the minimum distance between a bookshelf and a reading table with a chair as shown is $120 \mathrm{~cm}$.

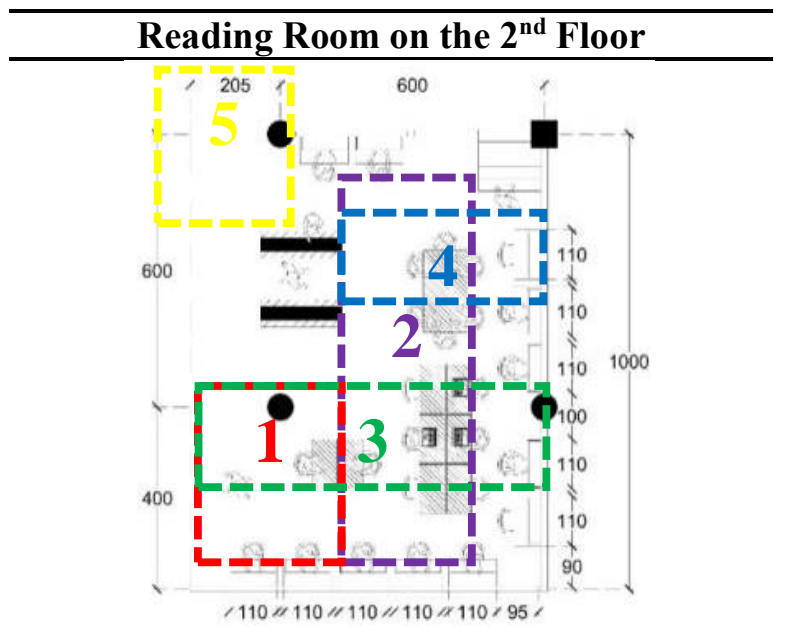

- The distance between reading tables in zone 1, which is in detail (1) has a distance of 155 $\mathrm{cm}$, the distance is in accordance with the recommended standard. While in detail (2), (3) and (4) have a distance between the reading table $65 \mathrm{~cm}-125 \mathrm{~cm}$, the distance will be narrow when the user makes a sitting and standing movements.

- And the distance between the reading table with a chair to the collection rack is $148 \mathrm{~cm}$, the distance has exceeded the recommended standard.

While the distance reading table on the stairs for $85 \mathrm{~cm}$ traffic road, the distance is too narrow and can interfere with users who will go up or down

(Source: Results of Analysis, 2019)

From the above table in the reading room of the $2^{\text {nd }}$ floor has a distance between the reading table that is not in accordance with the standards for effective circulation of space for the user, according to [10] the recommended distance size is $135 \mathrm{~cm}$ $150 \mathrm{~cm}$. While the distance between the reading table in the presence of a chair with a collection rack has a size that meets the standards, according to [10] 
the size of the distance between the reading table with a chair to the collection rack is $120 \mathrm{~cm}$.

\section{$3^{\text {rd }}$ Floor Reading Room}

In the reading room on the $3^{\text {rd }}$ floor library reading room of the University of Lampung there is a lesehan reading room, and 14 sitting chairs for visitors, on the reading room on the $3^{\text {rd }}$ floor there are several zone areas, as shown in the following figure:

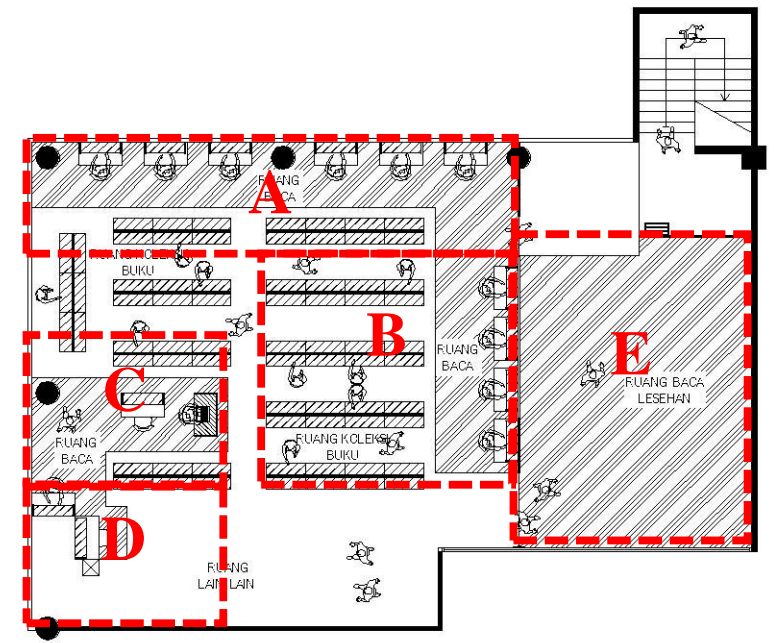

Figure 20. The Floor Reading Room Zone

\section{Information:}
A. Area1
B. Area2
C. Area 3
D. Area 4
E. Area 5

\section{Zone 1}

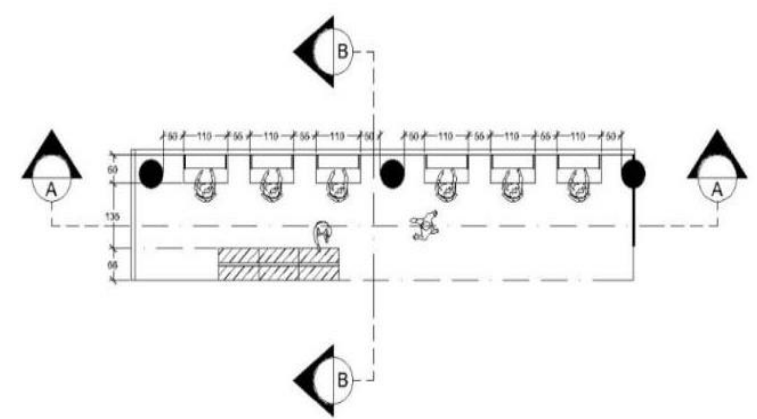

Figure 21. the r Floor Plan Reading Room Zone 1

In zone 1 reading room on the $3^{\text {rd }}$ floor, there are 6 units of personal reading tables provided for visitors. The distance between furniture in zone 1 is the distance between the reading table $55 \mathrm{~cm}$ and the distance between the reading table with a chair to the collection rack is $125 \mathrm{~cm}$, as shown in the following figure:

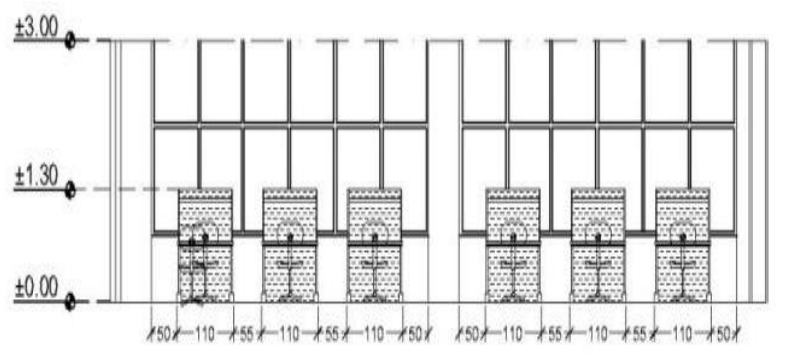

Figure 22. A-A Section Reading Room on the $3^{\text {rd }}$ Floor Zone 1 (Source: Author, 2018)

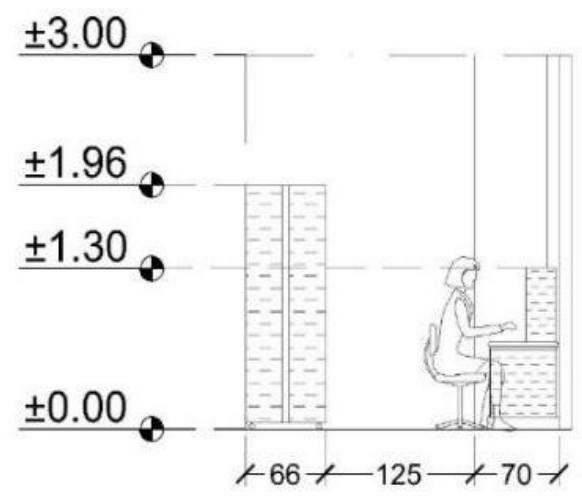

Figure 23. B-B Section Reading Room on the $3^{\text {rd }}$ Floor Zone 1

Zone 2

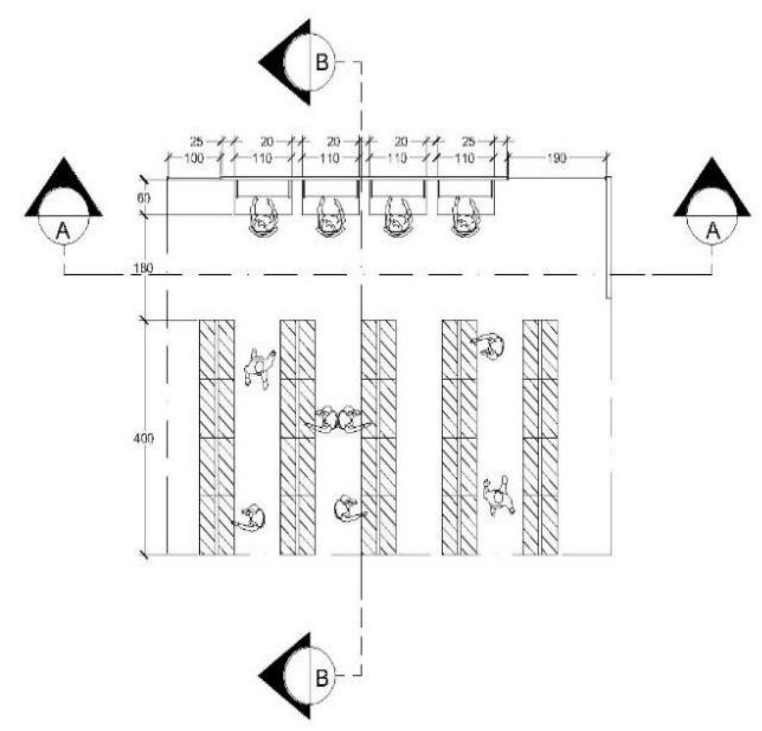

Figure 24. the $3^{\text {rd }}$ Floor Plan of Reading Room Zone 2

In zone 2 there are 4 reading table units and collection rack, the distance between the reading table with a chair to the collection rack is $180 \mathrm{~cm}$, as shown in the following figure: 


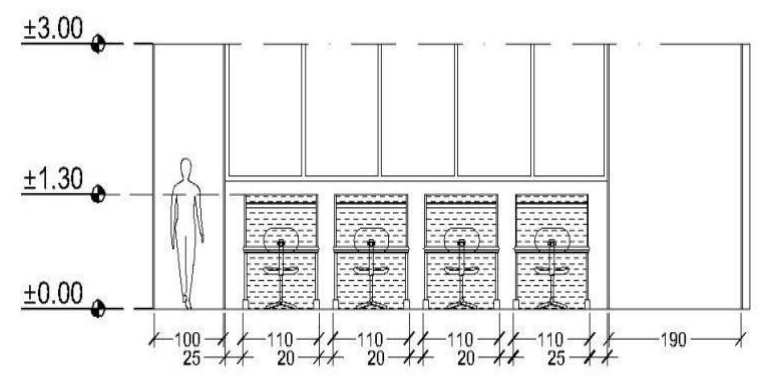

Figure 25. A-A Section of Reading Room on the $3^{\text {rd }}$ Floor Zone 2

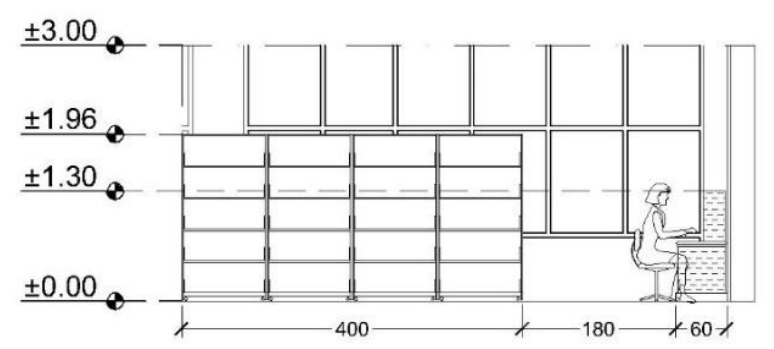

Figure 26. B-B Section of Reading Room on the $3^{\text {rd }}$ Floor Zone 2

\section{Zone 3}

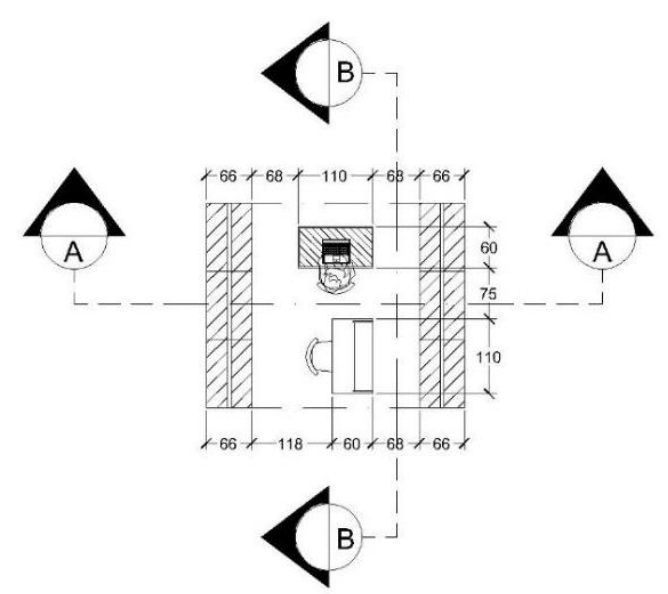

Figure 27. Reading Room Plan on the $3^{\text {rd }}$ Floor Zone 3

In zone 3 there are several types of furniture such as collection rack 3 , reading table 2 and reading table 3 , the distance between furniture in zone 3 is the distance between the reading table 75 $\mathrm{cm}$, the distance between the reading table without a chair to the collection rack $68 \mathrm{~cm}$ and the distance between the reading table with a chair with a collection rack that is $118 \mathrm{~cm}$.

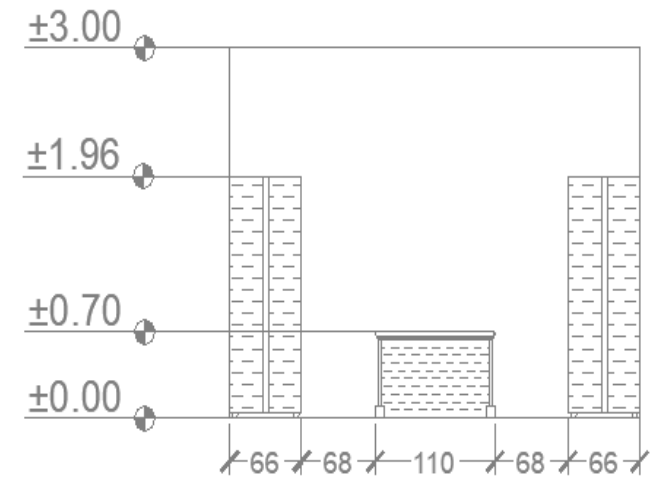

Figure 28. A-A Section of Reading Room on the $3^{\text {rd }}$ Floor Zone 3

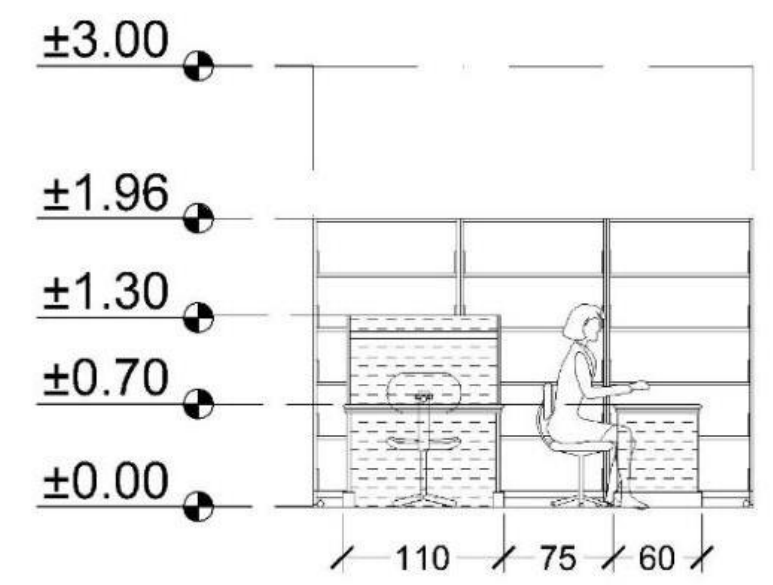

Figure 29. B-B Section of the $3^{\text {rd }}$ Floor Reading Room in Zone 3

\section{Zone 4}

In zone 4 there are 2 units of personal reading tables, which has a distance between the reading table with a wall that is $170 \mathrm{~cm}$, as in the following picture:

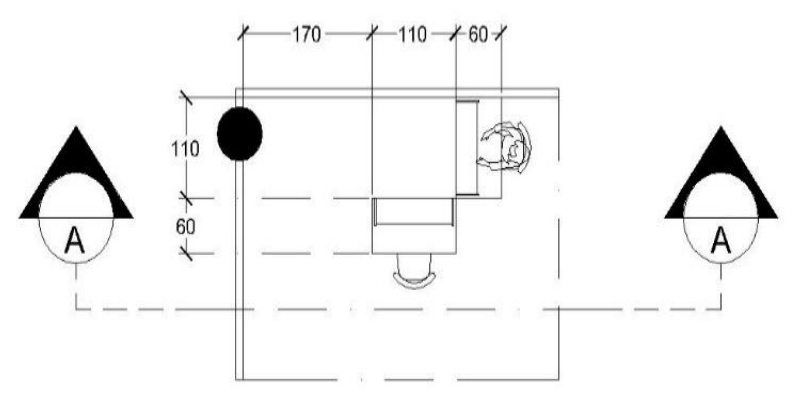

Figure 30. The $3^{\text {rd }}$ Floor Plan of Reading Room Zone 4 


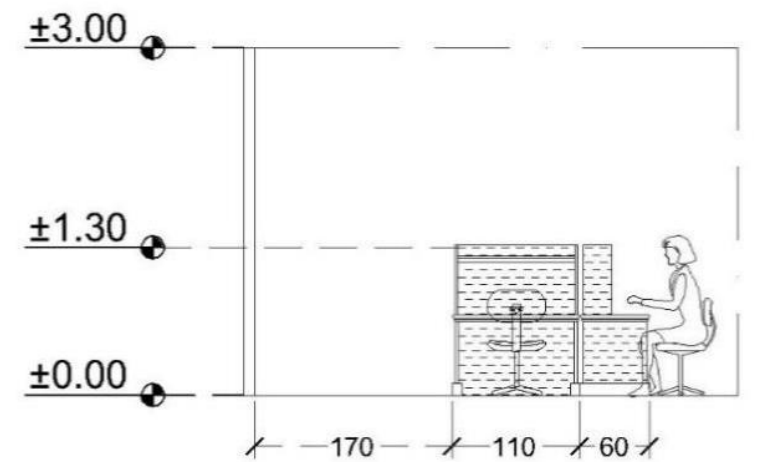

Figure 31. Section A-A Reading Room on the $3^{\text {rd }}$ Floor Zone 4 (Source: Data Private, 2018)

\section{Zone 5}

Zone 5 is a reading room for visitors, located separately from other zones.

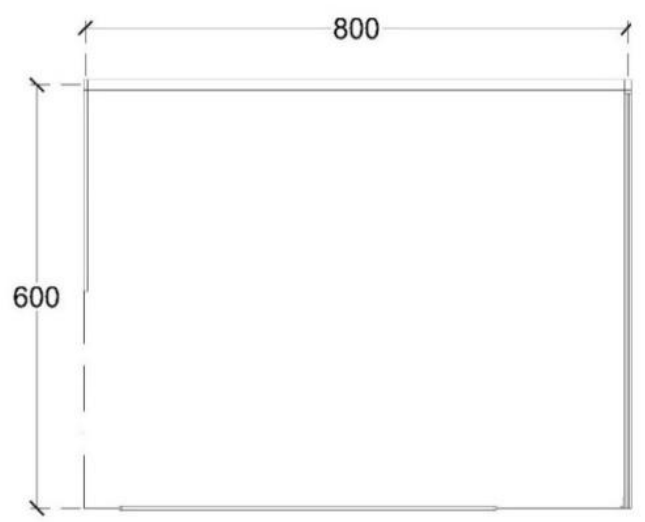

Figure 32. the $3^{\text {rd }}$ Floor Plan of Reading Room Zone 5

In the reading room on the $3^{\text {rd }}$ floor has a fairly good circulation of space in several zones inside. The following is a comparison of the standard analysis of the distance between the furniture in the reading room of the $3^{\text {rd }}$ floor.

Table 3. Comparison of the Size of the Furnitures Distance in the Reading Room on the $3^{\text {rd }}$ Floor Against the Standard

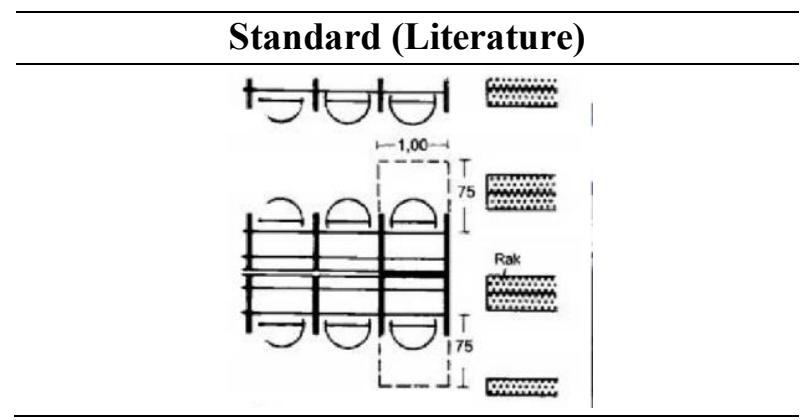

width of the personal table is $100 \mathrm{~cm}$ and the distance of the table to the chair sit $75 \mathrm{~cm}$.

The distance between tables that are back-toback with a chair is recommended at least 140 $\mathrm{cm}$.

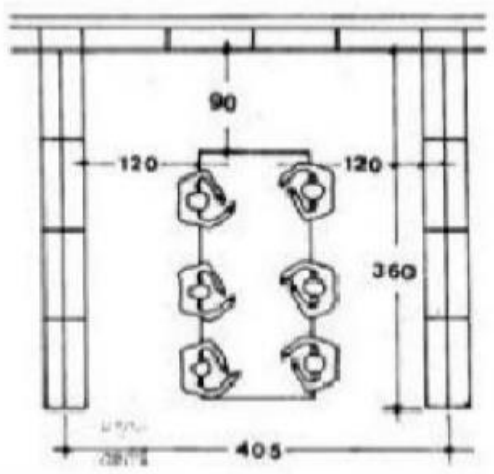

The minimum distance between a bookshelf and a reading table is $90 \mathrm{~cm}$ without a chair, while the minimum distance between a bookshelf and a reading table with a chair as shown is $120 \mathrm{~cm}$.

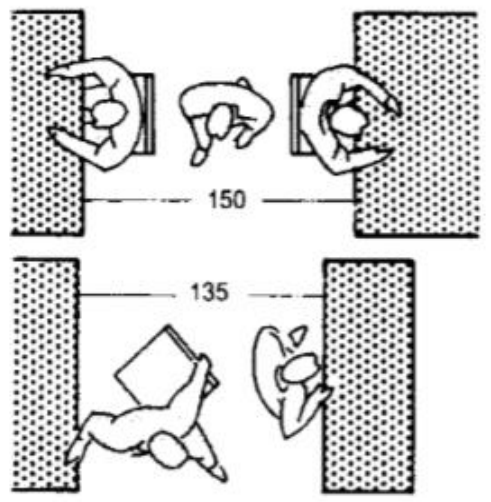

In the reading room activities that occur such as sitting, reading, walking requires minimum space within the range of the table when sitting position is $135 \mathrm{~cm}$, while the minimum distance between tables for movement of traffic when sitting and standing position is $150 \mathrm{~cm}$.

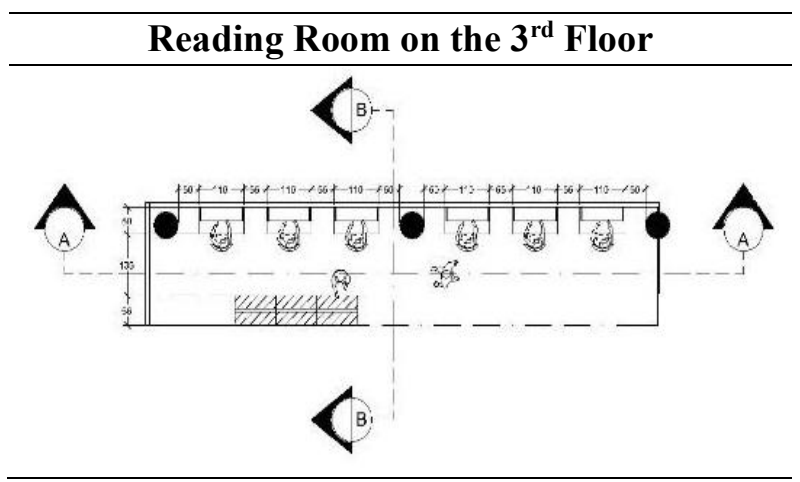


In the reading room 1 has a width of $110 \mathrm{~cm}$ personal table and the distance between the reading table with a chair with a collection rack of $135 \mathrm{~cm}$, the distance has met the standard.

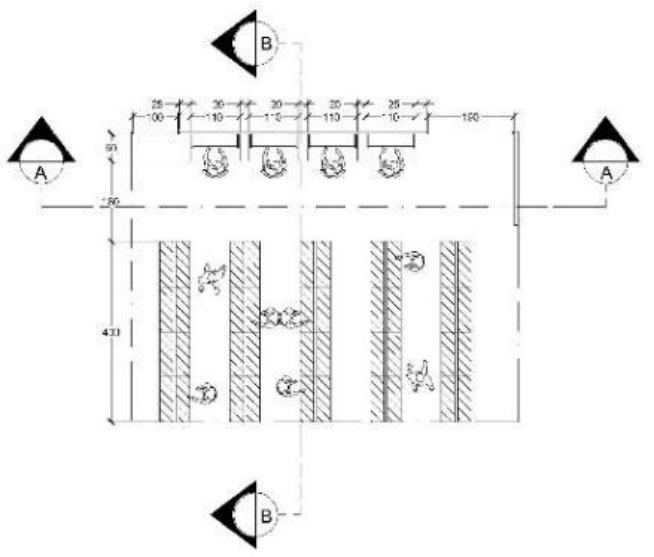

In the reading room 3 has a distance between the reading table with a chair with a collection rack of $180 \mathrm{~cm}$, the distance exceeds the standard size recommended distance.

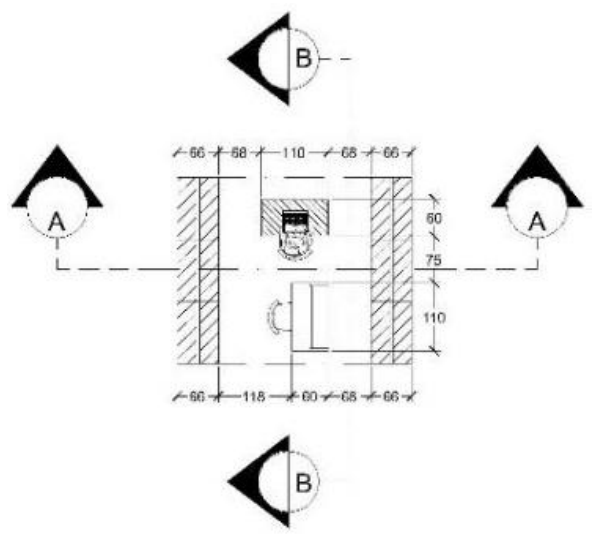

In the reading room 3 the distance between the reading table is $75 \mathrm{~cm}$, the distance is very narrow, resulting in the user not being able to freely move the position of sitting and standing. While the distance between the reading table with a chair with a $118 \mathrm{~cm}$ collection rack and without a chair $68 \mathrm{~cm}$. The distance is too narrow and ineffective for users to carry out their activities.

(Source: Results of Analysis, 2019)

From the Table 3 shows the circulation of the space in the reading room on the $3^{\text {rd }}$ floor has a circulation that does not meet the standard size for the distance between the reading table, according to [10] the recommended size is $135 \mathrm{~cm}-150 \mathrm{~cm}$. And the distance between the reading table without a chair with a collection rack also has a size that is less than the standard, while the distance between the reading table with a chair to the collection rack that distance already meets the recommended standard size, according to [10] the size of the distance between the reading table without a chair to the collection rack is $90 \mathrm{~cm}$ and the distance between the reading table with a chair to the collection rack is $120 \mathrm{~cm}$.

Based on the results of the analysis collected, an evaluation for the user's movement of circulation is obtained as follows:

Table 4. Comparison Results of the Size of the Furniture Distance in the Reading room University of Lampung Library Against Size Distance Standard

\begin{tabular}{|c|c|c|c|c|}
\hline Name Space & Between Furniture & $\begin{array}{l}\text { Size } \\
(\mathbf{c m})\end{array}$ & $\begin{array}{c}\text { Standard / } \\
\text { Literature } \\
(\mathrm{cm})\end{array}$ & Meet the standards \\
\hline Reading & Reading table - Reading table (area A) & 120 & 135-150 Reading & $\mathrm{X}$ \\
\hline $\operatorname{Room} 1^{\text {st }}$ & table - Reading table (area B) & 90 & 135-150 Reading & $\mathrm{X}$ \\
\hline \multirow[t]{2}{*}{ Floor } & table - Reading table (area B) (user traffic) & 170 & 135-150 Reading & $\checkmark$ \\
\hline & table without chairs - Collection shelves & 65 & 90 & $\mathrm{X}$ \\
\hline Reading & Reading table 2 - Reading table 3 & 155 & 135-150 Reading & $\checkmark$ \\
\hline $\operatorname{Room} 2^{\text {nd }}$ & table 2 - Reading table 3 & 100 & 135-150 Reading & $\mathrm{X}$ \\
\hline \multirow[t]{5}{*}{ Floor } & table 2 -3reading table & 97.5 & $135-150$ & $\mathrm{X}$ \\
\hline & reading table 3 - reading table & & $3125135-150$ & $\mathrm{X}$ \\
\hline & reading table 3 - 4reading table & & $70135-150$ & $\mathrm{X}$ \\
\hline & reading table 2 - see table 4 & 107.5 & $135-150$ & $\mathrm{X}$ \\
\hline & 4reading table with chairs - Shelves collection & 185 & 120 & $\checkmark$ \\
\hline Reading & Reading table 2 - Reading table 3 & 75 & 135-150 Reading & $\mathrm{X}$ \\
\hline $\operatorname{Room~} 3^{\text {rd }}$ & table 2 with chairs - Shelves collection 1 & 180 & 120 & $\checkmark$ \\
\hline \multirow[t]{2}{*}{ Floor } & Reading table 2 with chairs - Shelves collection 3 & 135 & 120 & $\checkmark$ \\
\hline & Reading table 2 years chair - Shelves collection 3 & 68 & 90 & $\mathrm{X}$ \\
\hline
\end{tabular}

(Source: Analysis Results, 2019) 
Based on the Table 4, circulation of movement space in the reading room of the University of Lampung (Unila) library in terms of the distance of the layout of the furniture is still considered to be poor and not yet meet anthropometric standards. After carrying out the process of measuring the distance of circulation space in the Unila library reading room some distance between furniture such as the distance between the collection shelves and the reading table in the presence of chairs and the distance between reading tables on the $1^{\text {st }}$ floor (zone B) exceeds the recommended standard size. While the distance between the collection shelves and the distance between the reading table does not meet the recommended standards.

\section{CONCLUSION}

Based on the results of the study it can be concluded that the circulation in the reading room of the University of Lampung library has not approached the distance of the circulation in accordance with standards. The distance between the bookshelves in the collection room and the distance between the reading table in the reading room is less than the standard, while the distance between the bookshelf and the reading table exceeds the recommended standard.

The distance between the furniture in the reading room of the $1^{\text {st }}$ to $3^{\text {rd }}$ floor UPT Library of the University of Lampung which includes the distance between the reading table in the reading room with activities that occur such as sitting, reading, walking also has poor circulation and space, with a distance of only $65 \mathrm{~cm}-100 \mathrm{~cm}$ not in accordance with the standard recommended by [10], which is $135 \mathrm{~cm}$, This distance causes the user to not be able to freely move the position of sitting and standing, while the distance between the tables for traffic on the $1^{\text {st }}$ floor already meets the standard recommended by [10], which is $150 \mathrm{~cm}$. The distance between the bookshelf and the reading table in the presence of a chair has exceeded the standard size between furniture recommended by [10], which is $120 \mathrm{~cm}$. But the distance between furniture that exceeds the standard can still be minimized again, so that it is more appropriate to the standard and becomes more effective.

The suggestions that can be obtained from this study are as follows: UPT Library Management University of Lampung pays more attention to the spatial layout of the reading room by considering circulation standard so that the circulation of the movement space inside can be more effective and efficient. Composition and area that exceeds the standard such as distance then cross between bookshelves with reading tables can be allocated for a narrow space such as the distance between the bookshelves in the collection room and the distance between the reading table in the reading room.

In accordance with [14] theory about the use of body ranges, in order to get good movement space, the designer must first understand and know the dimensions of the user's body and the patterns of user activity that are in the room or area.

Further research needed for identifying in circulation in collections room and the others room.

\section{ACKNOWLEDGMENTS}

Thank you to the Head of the Unila Library who gave permission for this research and all other assistance given to the authors.

\section{REFERENCES}

[1] Presiden RI (2007) Undang-Undang No. 43 tentang Perpustakaan. Indonesia, 2007.

[2] Presiden RI (1989) Undang-Undang No. 2 tentang Sistem Pendidikan Nasional. Indonesia, pp. 1-27.

[3] Qalyubi S (2007) Dasar-Dasar Ilmu Perpustakaan dan Informasi, UIN Sunan Kalijaga.

[4] Lancaster F W and Sandore B (1997) Technology and Management in Library and Information Services. University of Illinois., Illinois.

[5] Anugrah M P and Munawaroh A S (2017) Assessment Of Natural Lighting And Visual Comfort Of Library. (Case Study: Library Of Universitas Bandar Lampung And Universitas Teknokrat Indonesia). International Conference on Engineering and Technology Development (ICETD), pp. 464-475.

[6] Munawaroh A S and Nurbaiti F (2020) Kenyamanan Visual Pada Perpustakaan dan Kearsipan Daerah Bandar Lampung. Jurnal Arsir, vol. 3, no. 2, pp. 1-13.

[7] Munawaroh A S and Elbes R (2019) Penilaian kenyamanan termal pada bangunan perpustakaan Universitas Bandar Lampung. ARTEKS J. Tek. Arsit., vol. 4, no. 1, pp. 85-98.

[8] Munawaroh A S and Elbes R (2019) Persepsi Pengguna Terhadap Kenyamanan Termal Pada Bangunan Perpustakaan Ibi Darmajaya Lampung. Jurnal Arsitektur dan Perencanaan, vol. 2, no. 2, pp. 175-193.

[9] Ching Francis D K (2012) Arsitektur: Bentuk, Ruang dan Tatanan. Jakarta: Erlangga.

[10] Neufert E (2002) Data Arsitek Jilid 2. Jakarta: Erlangga. 
[11] Syah H (2010) Pengantar Umum Metodologi Penelitian Pendidikan Pendekatan Verivikatif. Pekanbaru: Suska Pres.

[12] Setyosari P (2010) Metode Penelitian Pendidikan dan Pengembangan. Jakarta: Kencana.

[13] Sukardi (2004) Metodologi Penelitian Pendidikan. Jakarta: Bumi Aksara.

[14] Panero J and Zelnik M (2003) Human Dimension \& Interior Space. Las Vegas: Whitney Library of Design.

J 2020 the Author(s), licensee Jurnal LINEARS. This is an open-access article distributed under the terms of the Creative Commons Attribution License

(http://creativecommons.org/licenses/by/4.0) 